\title{
INTERNAL FACTORS THAT STIMULATE THE INTERNATIONALIZATION OF COMPANIES IN PERU'S JEWELLERY SECTOR
}

\author{
Jhanira JARA, Paola ROMAN, Roxy SURICHAQUI, Wagner VICENTE-RAMOS (®* \\ Faculty of Management International Business, Continental University, Huancayo, Peru
}

Received 11 June 2020; accepted 4 August 2020

\begin{abstract}
The purpose of this research is to make known the internal factors that stimulate the internationalization of companies in the jewelery sector. We consider the qualitative approach at the descriptive level through semi-structured interviews with twelve major exporting companies in the jewelery sector in Peru. The results of the investigation show that the most relevant internal factors for the internationalization of jewelry companies is the international experience based on the understanding of markets, foreign clients, competition, knowledge of the documents and certificates necessary for an export, international commercial relations and risks in the negotiations; Another relevant internal factor is the personalization of the product with characteristics of innovation that generates better export results and, therefore, have a competitive position, since in the international market customers consider that companies have a product with added value, innovative and competitive. Moderately relevant factors are transaction costs, firm size, and the tacit nature of know-how; while opportunistic behaviuor is of little relevance. These findings will serve to understand opportunities and limitations that companies must be aware of to undertake new internationalization projects in the jewelery sector.
\end{abstract}

Keywords: internationalization, internal factors, exporting companies, jewelery sector, export, international experience, product customization, Peru.

JEL Classification: M16.

\section{Introduction}

Internationalization occurs when a company expands its research and development (R\&D), production, sales, and other commercial activities in international markets (Hollensen, 2014). In large companies, it can occur in a relatively continuous way, undertaking several stages in several foreign expansion projects simultaneously, over a period of time.

Companies that want to internationalize are generally driven by the development of open capacities in the domestic market that can be exploited in the foreign market (Chacar et al., 2010), since the commercialization of their product in the domestic market has a great acceptance by the national client (Olejnik \& Swoboda, 2012). That is why internationalization is a key driver of the company's growth and an important strategy for them to diversify their operational risk and thus obtain benefits (Leonidou, 2004), as well as allowing companies to improve their financial results (Lu \& Beamish, 2001).

The internationalization of small and medium-sized companies is often a relatively discreet process; that is, a management in stages prior to its expansion (Hollensen, 2014). In order for these companies to successfully internationalize, they must prioritize several factors that influence the internationalization and growth of companies in their market competition (Nakos \& Brouthers, 2002), so that companies can export goods or services, directly or through an intermediary (Love \& Roper, 2015). According to Golovko and Valentini (2011), there are different ways to internationalize, such as export and Foreign Direct Investment. Small companies will be able, through their internationalization process, to incorporate new technological advances, integrate, learn about new cultures and discover new lines of business. Thus, small and mediumsized companies will be able to obtain valuable knowledge and a series of experiences that will greatly benefit both product and process innovation (Craig \& Douglas, 2000).

Jewelry in Peru is a tradition that has been accepted in the international market, due to its artisan manufacturing, great possession, a wide variety of precious stones and the quality of the silver it offers (Barreto, 2016), therefore Peru is In 39th place in exports of 925 silver jewelry worldwide,

*Corresponding author. E-mail: wvicente@continental.edu.pe 
surpassed by Thailand, India and Germany, its main importer is the United States of America with a 50.1\% share of purchases in silver jewelry. Peru's exports in 2017 totaled US \$ 6,992 billion; in 2018 it decreased by $23.93 \%$, while in 2019 it decreased by $23.39 \%$ compared to 2018 (TradeMap, 2019).

Peru has 20 active exporting companies in the jewelery sector, however not all of them are producers, if not, they are intermediaries for small companies (Sistema Integrado de Información de Comercio Exterior, 2019), some specialists in the jewelery sector comment that there is a large number of workshops and production companies nationwide that exceed five thousand, which is mostly made up of small entrepreneurs (Campos \& Valencia, 2019).

The microentrepreneurs in the jewelery sector in Peru are formal and are found in various regions such as Junín, Ayacucho, Cusco, Arequipa and among others, who have years of experience in jewelry making due to family tradition, these microentrepreneurs seek to export, but find limitations to internationalization. The main problems affecting the direct non-export of its products are: Failing to offer the market jewelery with added value (ADEX, 2018), due to the lack of training for the operating personnel to elaborate designs according to the trends of the destination countries (Gonzales \& Sirlupú, 2017), therefore, there is no improvement in production processes (Mesa \& Torres, 2019). Small and medium-sized companies have limited management skills and do not acquire learning skills for international growth, so they do not have timely information about the export process and compliance with quality standards (Eulogio \& Pinares, 2015). Microentrepreneurs do not have the necessary financial resources and this limits the possibility of capturing business opportunities abroad (Korsakienè \& Tvaronavičiené, 2011); in turn, they do not have the necessary investment to develop new technological assets (Navas, 2017); therefore, they do not manage to expand their resources and capacities in an efficient way (Eulogio \& Pinares, 2015), this makes the company not attractive in the international market.

With this study, small, medium and large Peruvian companies in the jewelery sector will be made aware of the internal determining factors of internationalization that drive direct export without intermediaries to achieve a competitive advantage in an international market.

\section{Literature review}

\subsection{Internationalization}

Internationalization is the expansion of the company's operations to foreign markets and could result in specific and independent actions (Korsakienè \& Tvaronavičienè, 2011). It is defined as the process of mobilizing, accumulating and developing reserves of resources to exploit business opportunities across national borders (Ruzzier et al., 2006; Oviatt \& McDougall, 2005), as well as being a complex process that It integrates three stages: analysis of competitiveness factors (country, sector and company resources and capacities), formulation of strategies (entry, competitive and functional) and implementation (organizational design and control mechanisms) (Claver \& Quer, 2001).

When a company begins to carry out the internationalization process, it will face administrative, financial and related barriers regarding its activities in the international market. These challenges are related to the structural characteristics and strategic decisions made by the company (Katsikeas \& Morgan, 1994; Saeed \& Vincent, 2011; Azzi da Silva \& Da Rocha, 2001). Therefore, it will have to make incremental decisions in order to know and experience the international market (Olejnik \& Swoboda, 2012), in this way companies will increase their knowledge of foreign trade, as well as establish transactions in other countries and indirect influences of international transactions in their future (Paul et al., 2017).

\subsection{Internal factors of internationalization}

They refer to the financial, commercial, personal and administrative aspects (Navarrete \& Sensores, 2011), which positively or negatively generate an internationalization. Based on Hollensen (2014) the relevant internal factors of internationalization for companies are:

Know-how tacit nature; is the tacit knowledge that allows companies to order, use resources and develop new capabilities (Montazemi et al., 2012), can take the form of managerial skills and experiences (Zaizi, 2018). Marketing knowledge includes various factors to position a valuable brand (Wu, 2013), likewise, when companies expand nationally, they accumulate information about customer needs, preferences, prices and promotion (Xie \& O'Neill, 2014).

Likewise, the specific technical knowledge transferred such as contract writing, investment modes, organizational training, interpersonal, physical and manual skills must be used in a hierarchical way for adequate knowledge management in the company (Hollensen, 2014).

Opportunistic behavior; is the behavioral manifestation of opportunism, defined as behaviors by a contractor motivated to deceitfully pursue his own interest to achieve profit at the owner's expense (Das \& Rahman, 2010; Lu et al., 2016). The information carrier has more opportunities to behave opportunistically (Zhang \& Qinzhen, 2017), since it is defined as cunning pursuit of self-interest. On this basis, opportunism combines seeking self-interest with dishonest behavior, such as the disclosure of distorted or incomplete information and calculated efforts to deceive, distort, disguise, and otherwise confuse (Williamson, 1985).

To protect yourself from the dangers of opportunism, it is necessary to employ various types of safeguards, such as the control mechanism, which aims to achieve the perception of equity among operators, the purpose of which is to provide, at a minimum cost, control and trust as they are necessary for the seller and buyer involved in the exchange. The most prominent safeguard is the legal contract, which specifies the obligations of each party and 
allows an operator to go to a third party, as well as specified in a contract as clauses (Hollensen, 2014).

Transaction costs; a transaction occurs with the interaction between a supplier and a customer, these are related to the management, monitoring and control they have (Makhlouf, 2020). Transactions are not free. To carry them out, the actors incur transaction costs; To reduce transaction costs, participants design the way of managing the transaction, which are: the market, the hierarchy (organization) and strategic alliances (Gorbaneff et al., 2013).

Transaction costs limit the ability to use a contract to avoid inconvenience, reaching an agreement the transaction costs will depend on many factors, such as the information available, the complexity of the terms, as well as the ability to follow up (Carlton, 2019).

According to Hollensen (2014), transaction costs are divided into various forms, which are: ex ante costs that are made up of search and contracting costs, ex post costs made up of monitoring and execution costs.

Firm Size; the size of the company is considered according to the number of employees (Mahmoood \& Hamzah, 2018), likewise companies that have less than 125 employees will be considered small companies, those with 125 to 400 employees are considered medium-sized companies, of the In the same way, those with between 400 and 1,000 employees are called large companies (Peter \& Burker, 2017).

In the market, the size of the company does not directly affect performance, but it does influence the risk-taking relationship, proactivity and innovation. If a company is larger, its risk taking and proactivity would affect performance more significantly, it would also be more prone to innovation, since it has the capacity to face any failure that occurs (Mahmoood \& Hamzah, 2018).

International experience; is important as companies allow resources to be exchanged with various host countries, to better understand foreign markets and clients (Lages et al., 2008). Experiential knowledge is one of the resources that facilitates the company a faster entry into international markets (Oviatt \& McDougall, 2005), since it enables a company to rapidly expand beyond national borders (Autio et al., 2000; Zahra, 2005). The company's performance in international markets will allow it to experiment, explore and seek new knowledge through interaction with new cultures, new regulatory frameworks and new technological environments. This new knowledge will allow companies to develop new capabilities in the foreign market (Casillas et al., 2009), thanks to these actions, costs are reduced, as well as avoiding the uncertainty generated when wanting to enter the market. International, thereby committing companies to the responsibility of complying with the resources established in the countries.

Product Customization; the Customization of the product depends on the characteristics and use, since they are distinguished by physical variations, brand, advertising and after-sales (Hollensen, 2014). According to Paul et al. (2017), companies have the ability to introduce innovative products or services to the market and thus obtain competitive advantages over their competitors, this helps their internationalization process. Product life cycles are shorter, this leads entrepreneurs to innovate products and services and thus adopt internationalization strategies despite being new companies (Castaño et al., 2016).

Based on the described literary review and interviews with the main foreign trade managers of the Peruvian exporting companies in the jewelery sector, this qualitative research was carried out that will serve as a benchmark, support and theoretical background, so that companies interested in the internationalization of Its products can identify the internal determining factors that lead to success in the international market and thus boost the export of the jewelery sector, since it generates a competitive advantage for any company and country.

\section{Research method}

This research was based on a qualitative descriptive methodological design, in the exporting companies of the jewelery sector in Peru. The study used the semi-structured in-depth interviews instrument, which have been identified as very useful instruments in descriptive studies, because they will allow the experiences of the study subjects to be captured (Rivera et al., 2013).

The population consisted of 20 exporting companies, identified according to the following criteria: (i) be a formal company, (ii) be among the top 20 jewelry exporting companies and (iii) be registered in the PromPerú database (Commission for the Promotion of Peru for Export and Tourism) and MINCETUR (Ministry of Foreign Trade and Tourism). For the determination of the sample size, the companies that gave their consent to provide information based on their experience (12 companies) were considered.

For the collection of information, the semi-structured interview technique was used, aimed at 12 foreign trade managers of the Peruvian exporting companies in the jewelery sector, considered for their experience in the internationalization process.

The study variables of the internal factors for the internationalization of companies are based on Hollensen (2014).

For the processing of information and the elaboration of results, the analysis of qualitative data was used because the researcher induces in the studied problem from the interpretation of the individuals (in this study, the Foreign Trade Managers) who operate in reality. which is examined, in turn seeks to conceptualize reality based on the behavior, knowledge, values and attitudes of the people studied (Monje, 2011).

\section{Analysis of findings and discussion}

This section compiles the main findings acquired from the execution of the in-depth interviews, where interviews were conducted with twelve Foreign Trade managers of 
the various Peruvian exporting companies in the jewelery sector, these are in an age range (30-45 years old), who have more than ten years of experience in foreign trade, as well as various specializations in International Business. These informants were chosen for the investigation because they create and implement action plans to improve the performance of the collaborators, they also know the processes and internal structures of the company very well, they have the ability to identify and evaluate the extent of the business, having good Relative general notions of contracts, in such a way they seek and supervise participation in international fairs, analyzing market trends to determine where demand is pointing and that is why they have great sensitivity to negotiate with different cultures.

In this research, an interpretative analysis was carried out after the collection of information from the twelve study subjects, where each one provided what was related

Table 1. Contrasting the information of the Know-how tactical nature

\begin{tabular}{|c|c|c|c|}
\hline Subcategories & $\begin{array}{l}\text { Summary of informants' } \\
\text { expertise }\end{array}$ & $\begin{array}{l}\text { Theories according to Hernández } \\
\text { and Domínguez (2004) }\end{array}$ & $\begin{array}{l}\text { Conclusive summary of the } \\
\text { researchers }\end{array}$ \\
\hline $\begin{array}{l}\text { Formal } \\
\text { education }\end{array}$ & $\begin{array}{l}\text { Companies carry out training in } \\
\text { the administrative area at least } \\
\text { twice a year, they update their } \\
\text { collaborators with the latest trends } \\
\text { in international markets, sales and } \\
\text { logistics for a better organization. } \\
\text { In the operational area, training is } \\
\text { carried out once a year, which is } \\
\text { in charge of the management area. } \\
\text { On export issues, they participate } \\
\text { in trainings by Promperu and the } \\
\text { Lima Chamber of Commerce. }\end{array}$ & $\begin{array}{l}\text { Formal education is made up } \\
\text { of administrative training to } \\
\text { plan, organize, control and } \\
\text { exercise its functions based } \\
\text { on the management of its } \\
\text { human resources and technical } \\
\text { training related to the specific } \\
\text { skills involved with the correct } \\
\text { performance of a specific area. }\end{array}$ & $\begin{array}{l}\text { There is agreement between the ex- } \\
\text { pertise of the informants and the } \\
\text { author, since companies must carry } \\
\text { out administrative and operational } \\
\text { technical training based on their } \\
\text { human resources, which must be } \\
\text { carried out at least twice a year in } \\
\text { order to perform correctly in each } \\
\text { specific area for internationalization. }\end{array}$ \\
\hline $\begin{array}{l}\text { Professional } \\
\text { knowledge }\end{array}$ & $\begin{array}{l}\text { In order for companies to have a } \\
\text { good internationalization process, } \\
\text { each specific area necessarily } \\
\text { manages documents, written } \\
\text { manuals on manufacturing and } \\
\text { marketing processes. The use of } \\
\text { these materials is important to } \\
\text { avoid making future mistakes. }\end{array}$ & $\begin{array}{l}\text { Professional knowledge is a neces- } \\
\text { sary skill to function successfully } \\
\text { in a particular profession, it is de- } \\
\text { termined by work analysis proce- } \\
\text { dures and to be recognized as a } \\
\text { professional in a specific field. }\end{array}$ & $\begin{array}{l}\text { It is necessary to have professionals } \\
\text { with experience in specific areas rela- } \\
\text { ted to internationalization, as well as } \\
\text { knowledge of the use of documents, } \\
\text { written manuals referring to the manu- } \\
\text { facturing and marketing process. }\end{array}$ \\
\hline Cognitive skills & $\begin{array}{l}\text { The main cognitive skills expe- } \\
\text { rienced by employees in companies } \\
\text { are: communication and problem } \\
\text { solving; But the ability that has the } \\
\text { most impact for the growth of the } \\
\text { company is internal and external } \\
\text { communication. }\end{array}$ & $\begin{array}{l}\text { Cognitive skills are those that } \\
\text { relate to the information process, } \\
\text { involve the use of memory, } \\
\text { creativity, perception, prediction, } \\
\text { intuition, and problem solving. }\end{array}$ & $\begin{array}{l}\text { The most relevant cognitive skills that } \\
\text { company employees must have are } \\
\text { communication, creativity, memory } \\
\text { and problem solving. }\end{array}$ \\
\hline Physical skills & $\begin{array}{l}\text { Employees of companies have } \\
\text { certain skills such as manual and } \\
\text { visual dexterity for a good result } \\
\text { in products. Therefore, in the ope- } \\
\text { rational area for a worker to enter } \\
\text { the company, he must have a mini- } \\
\text { mum experience of three years in } \\
\text { jewelry making. }\end{array}$ & $\begin{array}{l}\text { Physical skills are qualities of } \\
\text { manual and visual dexterity that } \\
\text { are connected to a person's body, } \\
\text { rather than their mind. }\end{array}$ & $\begin{array}{l}\text { Company employees must have exten- } \\
\text { sive experience and physical skills of } \\
\text { manual and visual skills for jewelry } \\
\text { making. }\end{array}$ \\
\hline $\begin{array}{l}\text { Individual } \\
\text { interpersonal } \\
\text { skills }\end{array}$ & $\begin{array}{l}\text { The collaborators of the companies } \\
\text { interviewed possess interpersonal } \\
\text { skills and the most important are: } \\
\text { empathy, assertive communication, } \\
\text { self-confidence, ease in words and } \\
\text { creativity to achieve the company's } \\
\text { goals. }\end{array}$ & $\begin{array}{l}\text { Individual interpersonal skills are } \\
\text { behaviors and habits necessary for } \\
\text { proper interaction, to improve per- } \\
\text { sonal relationships, and to achieve } \\
\text { communication goals. }\end{array}$ & $\begin{array}{l}\text { There is agreement between the exper- } \\
\text { tise of the informants and the author. } \\
\text { Company employees must possess } \\
\text { interpersonal skills such as empathy, } \\
\text { assertive communication, self- } \\
\text { confidence and easy words. }\end{array}$ \\
\hline $\begin{array}{l}\text { Interpersonal } \\
\text { skills at } \\
\text { company level }\end{array}$ & $\begin{array}{l}\text { The collaborators of the companies } \\
\text { have a good relationship with their } \\
\text { importers because they carry out } \\
\text { the skills such as leadership, shared } \\
\text { vision and teamwork. Companies } \\
\text { are part of the Fair Trade program } \\
\text { and this builds trust for importers. }\end{array}$ & $\begin{array}{l}\text { Interpersonal skills at the company } \\
\text { level are about the behaviors neces- } \\
\text { sary to maintain an adequate inter- } \\
\text { action with the outside world. }\end{array}$ & $\begin{array}{l}\text { Company employees must have inter- } \\
\text { personal skills at the company level } \\
\text { such as shared vision, leadership, } \\
\text { teamwork and fair negotiation. }\end{array}$ \\
\hline
\end{tabular}


to the questions asked by the researchers. This ensured that the study categories could be extracted and could be defined for subsequent triangulation and contrast.

Next, the expertise of foreign trade managers is contrasted with reference theories.

\subsection{Tacit nature of Know-How}

From the contrast of the informants' expertise and the author's identified theory in Table 1 , it is determined that these characteristics are necessary for an adequate management of the tactical nature of Know-how in the internationalization of its products, since thanks to the development of knowledge and skills that collaborators possess; the company is successful in the international market, which is why it is a key factor in the organization. This finding is confirmed by Knight and Cavusgil (2004), which shows that the development of knowledge and organizational capacities support internationalization, performance and positioning in international markets, in this way companies find international success. Likewise, Lewin and Massini (2003) report that companies that develop the recombination of existing abilities and skills of collaborators, the creation of new knowledge based on their experience and updating routines promote successful growth in internationalization.

From the contrast of the informants' expertise and the author's identified theory, it is determined that these characteristics are necessary for an adequate management of the tactical nature of Know-how in the internationalization of its products, since thanks to the development of knowledge and skills that collaborators possess; the company is successful in the international market, which is why it is a key factor in the organization. This finding is confirmed by Knight and Cavusgil (2004), which shows that the development of knowledge and organizational capacities support internationalization, performance and positioning in international markets, in this way companies find international success. Likewise, Lewin and Massini (2003) report that companies that develop the recombination of existing abilities and skills of collaborators, the creation of new knowledge based on their experience and updating routines promote successful growth in internationalization.

\subsection{Opportunistic behavior}

Table 2 identified that the management of opportunistic behavior should be aimed at generating trust, that is why companies make contracts with the approval and consent of both parties, as well as the implementation of control mechanisms for the shipment of goods; In the same way, You et al. (2018) refer that in order to mitigate opportunistic behaviors, complex clauses must be drafted to adequately control what is established. Likewise, Xue et al. (2016) consider that trust and cooperative relationships between partners are crucial to maintain a good relationship since it works as effective defenses against opportunism.

\subsection{Transaction cost}

Table 3 shows the transaction costs that benefit the negotiation, search and pricing process for the internationalization of your products by means of search costs for experts and intermediaries, to avoid future errors and losses; contracting costs by digital and face-to-face means, using negotiation tactics for the agreement of both parties; monitoring costs to disclose customs documents that guarantee compliance with the obligations between both parties and thus avoid mistrust of the importer. The findings are corroborated with the

Table 2. Contrasting opportunistic behavioural information

\begin{tabular}{|c|c|c|c|}
\hline Subcategories & $\begin{array}{l}\text { Summary of informants' } \\
\text { expertise }\end{array}$ & $\begin{array}{l}\text { Theory according to Hollensen } \\
\text { (2014) }\end{array}$ & $\begin{array}{l}\text { Conclusive summary } \\
\text { of the researchers }\end{array}$ \\
\hline $\begin{array}{l}\text { Economic } \\
\text { opportunistic } \\
\text { behaviour }\end{array}$ & $\begin{array}{l}\text { It is important that values are } \\
\text { practiced within the company } \\
\text { that generally highlight ethics, } \\
\text { honesty, trust and punctuality. The } \\
\text { Managers of the Foreign Trade } \\
\text { area make specific purchase and } \\
\text { sale contracts with their importers } \\
\text { detailing rights and obligations } \\
\text { of both parties in order to avoid } \\
\text { economic opportunismo. }\end{array}$ & $\begin{array}{l}\text { Economic opportunism explains } \\
\text { problems in transactions, to avoid } \\
\text { this, safeguards must be used, for } \\
\text { the necessary control and trust. The } \\
\text { most prominent safeguard is the } \\
\text { legal contract, which specifies the } \\
\text { obligations of each party and allows an } \\
\text { operator to go to a third party (that is, } \\
\text { a court) to sanction an opportunistic } \\
\text { business partner. }\end{array}$ & $\begin{array}{l}\text { The managers of the Foreign Trade } \\
\text { area must make legal international } \\
\text { purchase and sale contracts } \\
\text { detailing rights and obligations } \\
\text { between both parties. }\end{array}$ \\
\hline $\begin{array}{l}\text { Political } \\
\text { opportunistic } \\
\text { behaviour }\end{array}$ & $\begin{array}{l}\text { In order not to have problems } \\
\text { when the merchandise is } \\
\text { sent to the international } \\
\text { market, companies verify the } \\
\text { corresponding documents through } \\
\text { a customs agent and export } \\
\text { specialists, in the event that a } \\
\text { document does not comply with } \\
\text { the specifications, it is rectified } \\
\text { with a customs agent. }\end{array}$ & $\begin{array}{l}\text { To protect yourself from political } \\
\text { opportunism that is capable of giving } \\
\text { up the fundamental principles to } \\
\text { achieve a particular benefit by harming } \\
\text { others, a variety of control mechanisms } \\
\text { or governance structure should be } \\
\text { employed, with the goal of achieving } \\
\text { equity among organizations. }\end{array}$ & $\begin{array}{l}\text { Companies must implement } \\
\text { control mechanisms for shipping } \\
\text { goods, such as document } \\
\text { verification through a customs } \\
\text { agent and export specialists to } \\
\text { protect themselves from political } \\
\text { opportunism. }\end{array}$ \\
\hline
\end{tabular}


study by Nikolaeva and Pletnev (2016) who consider that the companies that use these transaction costs increase their profits and the possibility of being successful, however those that do not implement these costs run the risk of being unproductive, Likewise, Brouthers and Nakos (2004) conclude that the transaction cost used by companies is a useful tool for making business decisions that facilitates entry and success in the international market.

\subsection{Firm size}

The findings of availability of resources, production and technology are evidenced in Table 4; is needed the adequate number of collaborators in the administrative and operational area to supply the required demand of the destination countries. Likewise, it is necessary to have several suppliers to avoid problems in the volume of production destined for export; regarding infrastructure, it is necessary to have adequate spaces to house technological machines and equipment based on international standards. The findings contradict the study by Aguilera et al. (2011) since they show that the size and the sector of the company do not influence internationalization because it is a strategic option, likewise Knight and Cavusgil (2004) refers that the lack of experience, the scarcity of financial, human and tangible resources, are no longer important impediments to large-scale internationalization and the international success of the company.

\subsection{International experience}

It was identified in Table 5 that the management of the international experience is based on the participation of international fairs, execution of a business plan one year in advance of the export, knowledge of the documents and certificates necessary for an export, international trade relations; Likewise, it is necessary to avoid the uncertainty of payment specifying $50 \%$ in advance and the other 50\% before the shipment of the merchandise, in this way the companies obtain greater benefits and competitive advantages in the market. This finding is confirmed by Aguilera et al. (2011) who demonstrated that the international expansion experienced by companies is based on generating organizational capacities, acquiring valuable knowledge and having a competitive advantage through their internationalization, likewise Autio et al. (2000) evidenced that the process of international expansion is valued through its degree of diversification and its international experience, this makes companies have the benefit of acquiring international knowledge.

Table 3. Contrasting transaction cost information

\begin{tabular}{|c|c|c|c|}
\hline Subcategories & $\begin{array}{l}\text { Summary of informants' } \\
\text { expertise }\end{array}$ & $\begin{array}{l}\text { Theory according to Hollensen } \\
\text { (2014) }\end{array}$ & $\begin{array}{l}\text { Conclusive summary } \\
\text { of the researchers }\end{array}$ \\
\hline Search costs & $\begin{array}{l}\text { Generally, companies in their first } \\
\text { years of export process do not have } \\
\text { the necessary experience to know new } \\
\text { international markets, for this reason, } \\
\text { they hired international business experts } \\
\text { to avoid mistakes and losses to the } \\
\text { company. In order for them to attract } \\
\text { clients, participation in international } \\
\text { fairs is necessary. }\end{array}$ & $\begin{array}{l}\text { Search costs are used to identify } \\
\text { and evaluate potential export } \\
\text { intermediaries. }\end{array}$ & $\begin{array}{l}\text { Companies must use search costs of } \\
\text { experts and intermediaries, to avoid } \\
\text { future mistakes and losses. }\end{array}$ \\
\hline $\begin{array}{l}\text { Recruitment } \\
\text { costs }\end{array}$ & $\begin{array}{l}\text { The representatives of the companies } \\
\text { make contracts by digital means such } \\
\text { as emails or social networks, in case the } \\
\text { purchase and sale is of large quantities, } \\
\text { contracts are made in person. } \\
\text { Negotiations are conducted through ne- } \\
\text { gotiation tactics and similarly uniquely } \\
\text { designed parts are offered at affordable } \\
\text { prices for equal parts compliance. }\end{array}$ & $\begin{array}{l}\text { Contracting costs refer to those } \\
\text { that are associated with the } \\
\text { negotiation and drafting of an } \\
\text { agreement between seller and } \\
\text { buyer. }\end{array}$ & $\begin{array}{l}\text { Company representatives must } \\
\text { employ digital contracting costs, } \\
\text { face-to-face contracting costs, using } \\
\text { negotiation tactics for the agreement } \\
\text { of both parties. }\end{array}$ \\
\hline $\begin{array}{l}\text { Monitoring } \\
\text { costs }\end{array}$ & $\begin{array}{l}\text { To avoid distrust of the importer, the } \\
\text { companies give part of the customs } \\
\text { documents that are being carried out } \\
\text { in the export process, in this way they } \\
\text { assure the importer that he sent the } \\
\text { merchandise and thus also generate } \\
\text { confidence. }\end{array}$ & $\begin{array}{l}\text { Monitoring costs are associated } \\
\text { with the agreement to guarantee } \\
\text { both the seller and the buyer } \\
\text { compliance with predetermined } \\
\text { obligations. }\end{array}$ & $\begin{array}{l}\text { The representatives of the compa- } \\
\text { nies must use monitoring costs to } \\
\text { disclose customs documents that are } \\
\text { carried out in the export process to } \\
\text { guarantee compliance with the ob- } \\
\text { ligations between both parties and } \\
\text { thus avoid mistrust of the importer. }\end{array}$ \\
\hline $\begin{array}{l}\text { Application } \\
\text { costs }\end{array}$ & $\begin{array}{l}\text { In case one of the parties, either the } \\
\text { exporter or the importer, does not } \\
\text { comply with one of the clauses specified } \\
\text { in the international purchase and sale } \\
\text { contract, they hire an international } \\
\text { arbitrator if in case a mutual agreement } \\
\text { is not reached. }\end{array}$ & $\begin{array}{l}\text { The application costs are } \\
\text { accompanied by the sanction of } \\
\text { a commercial partner who does } \\
\text { not comply with the agreement } \\
\text { agreed in a contract. }\end{array}$ & $\begin{array}{l}\text { Companies must use the costs of } \\
\text { applying a sanction to a partner } \\
\text { who fails to comply with one of the } \\
\text { clauses specified in the contract; } \\
\text { contract application costs to an } \\
\text { international arbitrator not to reach } \\
\text { an agreement on both sides. }\end{array}$ \\
\hline
\end{tabular}


Table 4. Contrasting firm size information

\begin{tabular}{|c|c|c|c|}
\hline Subcategories & $\begin{array}{l}\text { Summary of informants' } \\
\text { expertise }\end{array}$ & Theories & $\begin{array}{c}\text { Conclusive summary } \\
\text { of the researchers }\end{array}$ \\
\hline $\begin{array}{l}\text { Number of } \\
\text { workers }\end{array}$ & $\begin{array}{l}\text { The number of collaborators in a } \\
\text { company is important since thanks to } \\
\text { this a greater production is generated, } \\
\text { as well as streamlines the export } \\
\text { process. }\end{array}$ & $\begin{array}{l}\text { According to Martínez (2019), } \\
\text { the favors and benefits received } \\
\text { by workers form the basis of } \\
\text { symbolic capital that predominates } \\
\text { over economic capital within the } \\
\text { reproduction of social relations in } \\
\text { the system of an organization. }\end{array}$ & $\begin{array}{l}\text { Companies must have an adequate } \\
\text { number of collaborators in the } \\
\text { administrative and operational area } \\
\text { depending on the required demand } \\
\text { of the destination countries. }\end{array}$ \\
\hline $\begin{array}{l}\text { National } \\
\text { market share }\end{array}$ & $\begin{array}{l}\text { The companies have been positioned } \\
\text { in the national market for more } \\
\text { than fifteen years, thanks to online } \\
\text { advertising and participation in } \\
\text { national fairs. }\end{array}$ & $\begin{array}{l}\text { According to Ailawadi et al. } \\
(2001), \text { discount offers and } \\
\text { coupons increase market } \\
\text { penetration, but still do not retain } \\
\text { customers. Advertising increases } \\
\text { market share. }\end{array}$ & $\begin{array}{l}\text { Companies must invest in } \\
\text { advertising and participation in } \\
\text { national fairs to achieve a good } \\
\text { participation in the national } \\
\text { market. }\end{array}$ \\
\hline Technology & $\begin{array}{l}\text { The informants consider that in } \\
\text { the company it is essential to have } \\
\text { machines and that they have a } \\
\text { maintenance of at least once a year and } \\
\text { be in constant renovation, however, } \\
\text { the machines should be a maximum of } \\
\text { five years old since it is necessary for a } \\
\text { Good job in the production area and } \\
\text { in the administrative area. }\end{array}$ & $\begin{array}{l}\text { According to Cobo (2009), } \\
\text { technology is electronic computing } \\
\text { devices that allow the processing } \\
\text { and accumulation of enormous } \\
\text { amounts of information and a } \\
\text { rapid distribution of information } \\
\text { through communication networks } \\
\text { using qualitative data that analyzes } \\
\text { the behavior of information } \\
\text { systems and its influence on the } \\
\text { success of organizations. }\end{array}$ & $\begin{array}{l}\text { Companies must have } \\
\text { administrative information systems } \\
\text { that allow them to process and } \\
\text { accumulate information, high- } \\
\text { transfer communication networks, } \\
\text { machines and equipment with } \\
\text { operating technology for a better } \\
\text { production process. }\end{array}$ \\
\hline Resources & $\begin{array}{l}\text { The companies export at least ten } \\
\text { kilos of silver annually and it varies } \\
\text { according to the importers orders. } \\
\text { Being jewelry companies, they need } \\
\text { to have several suppliers so that they } \\
\text { do not have problems at the time of } \\
\text { production. }\end{array}$ & $\begin{array}{l}\text { According to Navarro et al. (2017), } \\
\text { resources are conceived as the } \\
\text { cornerstone of business results, } \\
\text { likewise the resources of the } \\
\text { exporting company are drivers, } \\
\text { the main ones of the exporting } \\
\text { enterprise. }\end{array}$ & $\begin{array}{l}\text { The companies have a high annual } \\
\text { production of silver jewelry, so } \\
\text { they must have several suppliers to } \\
\text { avoid problems in the production } \\
\text { volume. }\end{array}$ \\
\hline $\begin{array}{l}\text { Production } \\
\text { capacity }\end{array}$ & $\begin{array}{l}\text { The companies have } 15 \text { suppliers that } \\
\text { supply them with a minimum of } 13 \\
\text { kilos of silver and reach the maximum } \\
\text { capacity of } 60 \text { kilos annually for } \\
\text { export. The quantity of units that a kilo } \\
\text { of silver supplies varies according to } \\
\text { its design, but generally a kilo of silver } \\
\text { supplies for } 30 \text { necklaces, another kilo } \\
\text { for } 100 \text { pairs of earrings and finally } 50 \\
\text { rings per kilo of silver. }\end{array}$ & $\begin{array}{l}\text { According to Flórez (2006), the } \\
\text { production capacity of an active } \\
\text { company, it is enough to assess } \\
\text { the available resources, that is, to } \\
\text { measure the quantity and quality } \\
\text { of human resources, machines and } \\
\text { equipment, physical facilities, plant } \\
\text { distribution, system of production } \\
\text { and available working capital. }\end{array}$ & $\begin{array}{l}\text { Companies must have adequate } \\
\text { management of human resources, } \\
\text { materials, machines, infrastructure, } \\
\text { plant distribution and working } \\
\text { capital to have optimal production } \\
\text { capacity. }\end{array}$ \\
\hline Sales & $\begin{array}{l}\text { Companies use sales strategies such } \\
\text { as offering personalized pieces to the } \\
\text { international market and maintaining } \\
\text { a history in each one of them and also } \\
\text { that they are made by hand. } \\
\text { Every year, jewelry companies export } \\
\text { a minimum of 30,000 units, which are } \\
\text { earrings, necklaces and rings }\end{array}$ & $\begin{array}{l}\text { According to Franke and Park } \\
\text { (2006), companies trying to } \\
\text { improve sales performance often } \\
\text { encourage their adaptation and } \\
\text { strategies to achieve sales growth } \\
\text { goals. }\end{array}$ & $\begin{array}{l}\text { Companies must encourage } \\
\text { adaptation and develop marketing } \\
\text { strategies to achieve their sales } \\
\text { objectives, such as offering } \\
\text { customers personalized pieces that } \\
\text { promote the Peruvian culture to } \\
\text { have sales growth. }\end{array}$ \\
\hline Infrastructure & $\begin{array}{l}\text { The companies consider the work area } \\
\text { important so that the collaborators feel } \\
\text { comfortable, so that they have good } \\
\text { results, so they see the way to improve } \\
\text { the work environment, in this case the } \\
\text { companies mention that it is necessary } \\
\text { to improve the logistics area For a } \\
\text { good storage of merchandise, they also } \\
\text { have web pages. }\end{array}$ & $\begin{array}{l}\text { According to Ortiz et al. (2019), } \\
\text { the impact of infrastructure on } \\
\text { long-term national economic } \\
\text { growth is significantly greater than } \\
\text { the impact of business capital. }\end{array}$ & $\begin{array}{l}\text { Companies must have an } \\
\text { infrastructure with adequate space } \\
\text { to meet demand, specific areas } \\
\text { established separately highlighting } \\
\text { the area of logistics, comfortable } \\
\text { work environments. }\end{array}$ \\
\hline
\end{tabular}


Table 5. Contrasting international experience information

\begin{tabular}{|c|c|c|c|}
\hline Subcategories & $\begin{array}{c}\text { Summary of informants' } \\
\text { expertise }\end{array}$ & Theories & $\begin{array}{c}\text { Conclusive summary } \\
\text { of the researchers }\end{array}$ \\
\hline $\begin{array}{l}\text { International } \\
\text { market share }\end{array}$ & $\begin{array}{l}\text { The companies began to export more than } \\
17 \text { years ago, which is why they have the } \\
\text { necessary experience in the export process, } \\
\text { which is why they have acceptance in } \\
\text { the international market, especially in } \\
\text { the United States and some European } \\
\text { countries. Jewelry exports depend on the } \\
\text { festive seasons of the destination countries }\end{array}$ & $\begin{array}{l}\text { According to Ruble and Versaevel } \\
(2014), \text { when market share } \\
\text { is promoted through R\&D } \\
\text { cooperation, companies achieve } \\
\text { greater benefits. }\end{array}$ & $\begin{array}{l}\text { Companies must participate } \\
\text { in international fairs and } \\
\text { carry out direct exports to } \\
\text { gain greater international } \\
\text { experience and thus be able to } \\
\text { increase their R\&D. }\end{array}$ \\
\hline $\begin{array}{l}\text { Identifying } \\
\text { barriers }\end{array}$ & $\begin{array}{l}\text { The companies have the } 925 \text { silver law to } \\
\text { be able to export and consider that there } \\
\text { are no regulations that limit the export } \\
\text { of silver jewelry, except for the necessary } \\
\text { specifications that the certificate of origin } \\
\text { must have and thus avoid any error in the } \\
\text { aforementioned document. } \\
\text { Foreign markets value silver quality more } \\
\text { than designs. }\end{array}$ & $\begin{array}{l}\text { According to Botello (2016), the } \\
\text { possession of a quality certificate } \\
\text { by a company is a good measure } \\
\text { to be able to enter international } \\
\text { markets, likewise the possession of } \\
\text { a quality standard is not everything } \\
\text { to internationalize. }\end{array}$ & $\begin{array}{l}\text { The expertise of the } \\
\text { informants and the author } \\
\text { consider that companies that } \\
\text { want to start the process of } \\
\text { internationalization of silver } \\
\text { jewelry must have certificates } \\
\text { of origin that specify the } \\
\text { quality of silver (the } 925 \text { silver } \\
\text { law) for export. }\end{array}$ \\
\hline $\begin{array}{l}\text { Market } \\
\text { research }\end{array}$ & $\begin{array}{l}\text { In order for companies to know which } \\
\text { market to target, they participated in } \\
\text { international fairs and also received } \\
\text { guidance from the Internationalization } \\
\text { Support Program (PAI), thus attracting } \\
\text { new customers and constantly innovating } \\
\text { product designs according to tastes and } \\
\text { preferences the client's. }\end{array}$ & $\begin{array}{l}\text { According to Chiciudean et al. } \\
(2015) \text { The orientation of } \\
\text { consumer tastes and preferences } \\
\text { implies the use of marketing } \\
\text { research methodologies. }\end{array}$ & $\begin{array}{l}\text { Companies to initiate market } \\
\text { research must participate in } \\
\text { international fairs, consider the } \\
\text { results of international market } \\
\text { research from PAI, PromPerú } \\
\text { and others. }\end{array}$ \\
\hline $\begin{array}{l}\text { Compe- } \\
\text { titiveness }\end{array}$ & $\begin{array}{l}\text { Companies keep their skills updated } \\
\text { according to platforms that show export } \\
\text { results annually. In order for the product } \\
\text { to be shipped to the destination country, } \\
\text { the company focuses on studying the } \\
\text { tastes and preferences of that market so } \\
\text { that it has a good acceptance. }\end{array}$ & $\begin{array}{l}\text { According to Falciola et al. (2020) } \\
\text { Competitiveness refers to the } \\
\text { fact that companies must have } \\
\text { the capacity to satisfy consumer } \\
\text { demand in quantity, quality, and } \\
\text { price to their target segment of } \\
\text { the product and be adjusting to } \\
\text { changes in the market. }\end{array}$ & $\begin{array}{l}\text { To be competitive in the } \\
\text { international market, it is } \\
\text { important to consider the } \\
\text { exportable supply capacity, } \\
\text { quality, price to its segment, } \\
\text { permanent updating of product } \\
\text { design. }\end{array}$ \\
\hline Business plan & $\begin{array}{l}\text { Before the company enters a foreign } \\
\text { market, it first carries out a business plan } \\
\text { at least one year before its export to see } \\
\text { if its product will be accepted or not, by } \\
\text { doing this process it prevents the company } \\
\text { from causing losses. }\end{array}$ & $\begin{array}{l}\text { According to Honig and } \\
\text { Samuelsson (2020), They define } \\
\text { a business plan as a written } \\
\text { document that establishes the } \\
\text { idea of a business, which has } \\
\text { the objectives of identifying its } \\
\text { opportunity and using tools to } \\
\text { attract resources for financing. }\end{array}$ & $\begin{array}{l}\text { Companies must carry out a } \\
\text { business plan at least one year } \\
\text { before export. }\end{array}$ \\
\hline Uncertainty & $\begin{array}{l}\text { In order for companies to avoid payment } \\
\text { uncertainty, they enter into contracts } \\
\text { specifying the method, which is why they } \\
\text { work with the } \\
50 \% \text { advance and the other } 50 \% \text { before } \\
\text { shipment. } \\
\text { For the company to have constant } \\
\text { growth, it is necessary to be present } \\
\text { at international fairs so that they can } \\
\text { innovate their products. }\end{array}$ & $\begin{array}{l}\text { According to Yarba and Guner } \\
\text { (2020), Uncertainty is considered } \\
\text { as something negative, so } \\
\text { companies must foresee in the } \\
\text { markets and in this way minimize } \\
\text { risks and increase possibilities of } \\
\text { making profits. }\end{array}$ & $\begin{array}{l}\text { Companies must avoid } \\
\text { payment uncertainty specifying } \\
50 \% \text { in advance and the other } \\
50 \% \text { before the shipment of the } \\
\text { merchandise. }\end{array}$ \\
\hline
\end{tabular}

\subsection{Product customization}

It was identified in Table 6 that the management of the nature of the product for internationalization is focused on the quality, differentiation and variety of artisan products, through jewelry designs according to the tastes and preferences of the client. This finding supports the previous study by Franke et al. (2010) that demonstrated that the product with differentiation advantage is the potential impact of product customization, thus allowing the client to 
Table 6. Contrasting product personalization information

\begin{tabular}{|c|c|c|c|}
\hline Subcategories & $\begin{array}{l}\text { Summary of informants' } \\
\text { expertise }\end{array}$ & $\begin{array}{l}\text { Theories according to Porter } \\
\text { (2009) }\end{array}$ & $\begin{array}{l}\text { Conclusive summary } \\
\text { of the researchers }\end{array}$ \\
\hline Product quality & $\begin{array}{l}\text { To avoid product errors, companies have a } \\
\text { quality control area so that they can verify } \\
\text { possible errors in the parts. } \\
\text { One of the advantages that companies } \\
\text { have over international competitors is that } \\
\text { the products they offer are handcrafted. } \\
\text { Foreign markets require that companies } \\
\text { have the certification of origin and the } \\
\text { most important that silver pieces have the } \\
\text { stamp of the } 925 \text { law. }\end{array}$ & $\begin{array}{l}\text { The quality of a product refers } \\
\text { to the size, shape, technology, } \\
\text { reliability, consistency, durability, } \\
\text { and pre-sale and after-sales service. }\end{array}$ & $\begin{array}{l}\text { Companies must produce } \\
\text { artisan silver jewelery with } \\
\text { different sizes and shapes, with } \\
\text { the " } 925 \text { " seal for export and } \\
\text { offer a quality product with } \\
\text { durability. }\end{array}$ \\
\hline Product price & $\begin{array}{l}\text { Companies set the price of the product } \\
\text { according to the weight, design and } \\
\text { customization of the piece according to the } \\
\text { destination country. }\end{array}$ & $\begin{array}{l}\text { According to Sánchez et al. (2015), } \\
\text { when setting the price, variables } \\
\text { such as defining the target segment } \\
\text { and market, determining the cost } \\
\text { of the product, establishing the } \\
\text { positioning of the product and } \\
\text { knowing the market share of the } \\
\text { product in the industry should be } \\
\text { considered. }\end{array}$ & $\begin{array}{l}\text { Companies must set the price } \\
\text { of the product according } \\
\text { to the weight, design and } \\
\text { customization of the piece } \\
\text { according to the destination } \\
\text { country. }\end{array}$ \\
\hline $\begin{array}{l}\text { Variety of the } \\
\text { product }\end{array}$ & $\begin{array}{l}\text { The products that export the most are } \\
\text { earrings and necklaces, the countries that } \\
\text { acquire these products in greater quantity } \\
\text { are the United States and the United } \\
\text { Kingdom. }\end{array}$ & $\begin{array}{l}\text { According to Ramos et al. (2010), } \\
\text { the variety in products is the } \\
\text { diversification that a company } \\
\text { provides to the market. }\end{array}$ & $\begin{array}{l}\text { Companies must focus on } \\
\text { the needs and tastes of the } \\
\text { international customer, as } \\
\text { well as accept the opinions of } \\
\text { customers for modifications } \\
\text { and product customization. }\end{array}$ \\
\hline
\end{tabular}

participate in the design process so that the experience be different and also create economic value for customers. Likewise, Azar and Ciabuschi (2017) refers that adopting innovations to the product for the development of a foreign market are beneficial for export performance.

\section{Conclusions}

Based on the research findings, the theory of internal factors for the internationalization process of exporting companies in the jewelery sector becomes important (Hollensen, 2014). The companies interviewed consider as the most relevant factor the international experience that the leaders of the companies must have, because it is essential to understand markets, foreign clients, competition, knowledge of the documents and certificates necessary for an export, international trade relations and risks in negotiations, in this way companies benefit from their international expansion process and increase their international knowledge. Also the personalization of the product is a very relevant factor because it allows to obtain better results in the export and, therefore, to have a competitive position, since in the international market the clients consider decisive that the companies have a product with added value, innovative and competitive.

Regarding the tactical nature of Know-How, it is a moderately relevant factor in the success of the internationalization of companies in the jewelery sector, since the transmission of knowledge between collaborators must be considered so that they stand out in the market according to their functions, from In this way, achieve a competitive advantage, differentiating yourself from the competition and reaching leadership positions in the international market. Additionally, the transaction of costs is a moderately relevant factor because it is necessary for a good operation in the market through, costs of searching for experts and intermediaries, costs of contracting by digital and face-to-face means; monitoring costs of releasing customs documents and costs of applying sanction to a partner. Those that lead to being competitive and thus companies benefit their international growth. Likewise, the size of the company is a moderately relevant factor because it is necessary to meet the demands of the international market through a good infrastructure, availability of human and material resources, technology that helps the production process to supply demand and generate higher sales.

Opportunistic behavior is a little relevant factor, because companies should not have an opportunistic behavior practice, on the contrary, they should ethically manage the economic and political opportunistic behavior of their environment through legal formalization and permanent control of their relationships, because When generating it, companies take care of their prestige and positioning in the market.

The findings of this research work contribute to a better understanding of the reality of exporting companies in the jewelery sector, based on the Peruvian experience, and also show that the companies studied had to go through a comprehensive process of studies, research and constant 
participation in institutions that encourage exports so that they can enter the international market and meet their target audience.

\section{Limitations and future work}

The articles we examine address specific aspects of the research that reinforce informants' opinions, as we also find articles that refute them. This research is a qualitative descriptive study in twelve exporting companies in the Peruvian jewelery sector, the findings of which cannot be generalized to other companies that do not belong to the sector.

Despite the studies and findings, the subject of the internationalization of companies remains attractive, which is why further exploration and quantitative research based on the criteria of international competitiveness is recommended.

This research advises future studies to examine what are the external factors that companies should know before going international. Such studies will inform companies that are interested in applying them.

\section{Acknowledgements}

The authors appreciate the support of the representatives of the exporting companies in Peru's most important jewellery sector, for giving us the interview for gathering information on internal factors that stimulate internationalization.

\section{Author contributions}

Jhanira Jara, conceived the study and was responsible for the design and development of findings.

Paola Roman, was responsible for data collection and analysis of results.

Roxy Surichaqui, were responsible for data interpretation.

Wagner Vicente, wrote the first draft of the article.

\section{Disclosure statement}

The authors do not have any conflict of interest.

\section{References}

ADEX. (2018). Arequipa goza de potencial para abastecer de insumos a joyeros del sur peruano. Lima, de. https://www.adexperu.org.pe/notadeprensa/arequipa-goza-de-potencial-paraabastecer-de-insumos-a-joyeros-del-sur-peruano/

Ailawadi, K., Lehmann, D., \& Neslin, S. (2001). Market response to a major policy change in the marketing mix: learning from Procter \& Gamble's value pricing strategy. Journal of Marketing, 65(1), 44-61. https://doi.org/10.1509/jmkg.65.1.44.18130

Aguilera, J., Escudero, M., Hurtado, N., \& Vidal, M. (2011). The influence of international diversification and international experience on the firms' proactive environmental strategy. Investigaciones Europeas de Dirección y Economía de la Empresa, 17(1), 75-91. https://doi.org/10.1016/S1135-2523(12)60045-8
Autio, E., Sapienza, H., \& Almeida, J. (2000). Effects of age at entry, knowledge intensity, and imitability on international growth. Academy of Management Journal, 5(2000), 909-924. https://doi.org/10.2307/1556419

Azar, G., \& Ciabuschi, C. (2017). Organizational innovation, technological innovation, and export performance: The effects of innovation radicalness and extensiveness. International Business Review, 26(2), 324-336. https://doi.org/10.1016/j.ibusrev.2016.09.002

Azzi da Silva, P., \& Da Rocha, A. (2001). Perception of export barriers to Mercosur by Brazilian firms. International Marketing Review, 18(6), 589-611. https://doi.org/10.1108/EUM0000000006296

Barreto, G. (2016). Exportación de joyas de plata con incrustaciones de piedras naturales a Chile. Universidad de Lima, Lima, Perú. http://repositorio.ulima.edu.pe/bitstream/handle/ulima/1732/ Barreto_Rimay_Giancarlo.pdf? sequence $=1$ \&isAllowed $=y$

Botello, H. (2016). The effect of quality certification and the internationalization of Colombian industrial companies. Suma de Negocios, 7(16), 73-81. https://doi.org/10.1016/j.sumneg.2016.02.009

Brouthers, K., \& Nakos, G. (2004). SME entry mode choice and performance: a transaction cost perspective. Entrepreneurship Theory and Practice, 28(3), 229-247. https://doi.org/10.1111/j.1540-6520.2004.00041.x

Campos, Y., \& Valencia, S. (2019). Factores criticos que afectan la exportación en joyeria en plata peruana 925 no artesanal a los Estados Unidos durante los años 2013-2017. Universidad Peruana de Ciencias Aplicadas, Lima, Perú. http://hdl.handle.net/10757/625690

Carlton, D. (2019). Transaction costs and competition policy. International Journal of Industrial Organization (in press). https://doi.org/10.1016/j.ijindorg.2019.102539

Casillas, J., Moreno, A., Acedo, F., \& Gallego, M. (2009). An integrative model of the role of knowledge in the internationalization process. Journal of World Business, 44(3), 311-322. https://doi.org/10.1016/j.jwb.2008.08.001

Castaño, M., Mendez, M., \& Galindo, M. (2016). Innovation, internationalization and business-growth expectations among entrepreneurs in the services sector. Journal of Business Research, 69(5), 1690-1695. https://doi.org/10.1016/j.jbusres.2015.10.039

Chacar, A., Newburry, W., \& Vissa, B. (2010). Bringing institutions into performance persistence research: Exploring the impact of product, financial, and labor market institutions. Journal of International Business Studies, 41, 1119-1140. https://doi.org/10.1057/jibs.2010.3

Chiciudean, G., Arion, F., \& Muresan, J. (2015). Marketing oriented and sales-oriented companies in the agro-food industry. Economics and Rural Development, 72(2), 476-482. https://doi.org/10.15835/buasvmcn-hort:11491

Claver, E., \& Quer, D. (2001). La dirección estratégica de la internacionalización de la empresa: Propuesta de un marco teórico integrador. Revista de Economía, 1(794), 37-60.

http://www.revistasice.com/index.php/ICE/article/view/250

Cobo, J. (2009). El concepto de tecnologías de la información. Benchmarking sobre las definiciones de las TIC en la sociedad del conocimiento. Revista de estudios de comunicación, 14(27), 295-318.

Craig, C., \& Douglas, S. (2000). International marketing research ( $2^{\text {a }}$ ed.). Wiley.

Das, T., \& Rahman, N. (2010). Determinants of partner opportunism in strategic alliances: a conceptual framework. Journal of Business and Psychology, 25, 55-74. https://doi.org/10.1007/s10869-009-9132-2 
Eulogio, J., \& Pinares, S. (2015). Factores determinantes del bajo nivel de exportación directa de joyería y orfebrería en San Jerónimo de Tunán, Huancayo, 2015. Universidad Nacional del Centro del Perú, Huancayo, Perú. http://repositorio.uncp.edu. pe/bitstream/handle/UNCP/1533/TESIS\%20EULOGIO\%20 PINARES.pdf? sequence $=1$ \&isAllowed $=y$

Falciola, J., Jansen, M., \& Rollo, V. (2020). Defining firm competitiveness: A multidimensional framework. World Development, 129. https://doi.org/10.1016/j.worlddev.2019.104857

Flórez, J. (2006). Proyectos de Inversión para las PYME Creación de empresas ( $1^{\mathrm{a}} \mathrm{ed}$.). Ecoe.

Franke, G., \& Park, J. (2006). Salesperson adaptive selling behavior and customer orientation: a meta-analysis. Journal of Marketing Research, 43(4), 693-702. https://doi.org/10.1509/jmkr.43.4.693

Franke, N., Schreier, M., \& Kaiser, U. (2010). The "I Designed It Myself" effect in mass customization. Management Science, 56(1), 125-140. https://doi.org/10.1287/mnsc.1090.1077

Golovko, E., \& Valentini, G. (2011). Exploring the complementarity between innovation and export for SMEs' growth. Journal of International Business Studies, 42(3), 362-380. https://doi.org/10.1057/jibs.2011.2

Gonzales, P., \& Sirlupú, I. (2017). Los factores básicos en el proceso de innovación y su influencia en la competitividad de las empresas artesanales de joyería de plata. Universidad San Ignacio de Loyola, Lima, Perú. http://repositorio.usil.edu.pe/ bitstream/USIL/2674/1/2017_Gonzales_Los_factores_basicos_en_el_proceso_de_innovacion.pdf

Gorbaneff, Y., Cortes, A., Torres, S., \& Yepes, F. (2013). Transaction costs theory, governance modes and incentives in Colombia: a case study. Estudios Gerenciales, 29(128), 332-338. https://doi.org/10.1016/j.estger.2013.09.007

Hernández, J., \& Domínguez, M. (2004). Medición de la variable conocimiento: Una prueba empírica en las Organizaciones Artesanales de Oaxaca, México. Revista Escuela de Administración de Negocios, (51), 96-121.

Honig, B., \& Samuelsson, M. (2020). Business planning by intrapreneurs and entrepreneurs under environmental uncertainty and institutional pressure. Technovation.

https://doi.org/10.1016/j.technovation.2020.102124

Hollensen, S. (2014). Global marketing 2014 (7a ed.). Pearson. https://doi.org/10.15358/9783800649297

Katsikeas, S., \& Morgan, R. (1994). Differences in perceptions of exporting problems based on firm size and export market experience. European Journal of Marketing, 28(5), 17-35. https://doi.org/10.1108/03090569410062014

Knight, G., \& Cavusgil, S. (2004). Innovation, organizational capabilities, and the born-global firm. Journal of International Business Studies, 35(4), 334-334. https://doi.org/10.1057/palgrave.jibs.8400096

Korsakienè, R., \& Tvaronavičienè, M. (2011). The internationalization of SMES: an integrative approach. Journal of Business Economics and Management, 13(2), 294-307. https://doi.org/10.3846/16111699.2011.620138

Lages, L., Jap, S., \& Griffith, D. (2008). The role of past performance in export ventures: a short-term reactive approach. Journal of International Business Studies, 39(2), 304-325. https://doi.org/10.1057/palgrave.jibs.8400339

Leonidou, L. (2004). An analysis of the barriers hindering small business export development. Journal of Small Business Management, 42(3), 279-302.

https://doi.org/10.1111/j.1540-627X.2004.00112.x

Lewin, A., \& Massini, S. (2003). Knowledge creation and organizational capabilities of innovating and imitating firms.
Organizations as Knowledge Systems, 209-237. https://doi.org/10.1057/9780230524545_10

Love, J., \& Roper, S. (2015). SME innovation, exporting and growth: A review of existing evidence. International Small Business Journal: Researching Entrepreneurship, 33(1), 28-48. https://doi.org/10.1177/0266242614550190

Lu, J., \& Beamish, P. (2001). The internationalization and performance of SMEs. Strategic Management Journal, 22(6/7), 565-586. https://doi.org/10.1002/smj.184

Lu, W., Zhang, L., \& Zhang, L. (2016). Effect of contract completeness on contractors' opportunistic behavior and the moderating role of interdependence. Journal of Construction Engineering and Management, 142(6).

https://doi.org/10.1061/(ASCE)CO.1943-7862.0001110

Mahmood, Y., \& Hamzah, K. (2018). Mediating role of innovation and enterprise size between entrepreneur and enterprises performance. Revista de Ciencia Humanas y Sociales, 34(17), 798-819.

Makhlouf, R. (2020). Cloudy transaction costs: a dive into cloud computing economics. Journal of Cloud Computing: Advances, Systems and Applications, 9(1).

https://doi.org/10.1186/s13677-019-0149-4

Martínez, L. (2019). Clientelism in agribusinesses in Ecuador: Bussinessmen and rural workers. European Review of Latin American and Caribbean Studies, 75-94. https://doi.org/10.32992/erlacs.10415

Mesa, F., \& Torres, R. (2019). Pymes manufactureras exportadoras en Colombia: Un análisis de su actividad real. Lecturas de Economía, (90), 127-157. https://doi.org/10.17533/udea.le.n90a05

Monje, C. (2011). Metodología de la investigación cuantitativa y cualitativa. Universidad Surcolombiana.

Montazemi, A., Pittaway, J., Qahri-Saremi, H., \& Wei, Y. (2012). Factors of stickiness in transfers of know-how between MNC units. The Journal of Strategic Information Systems, 21(1), 31-57. https://doi.org/10.1016/j.jsis.2012.01.001

Nakos, G., \& Brouthers, K. (2002). Entry mode choice of SMEs in central and eastern Europe. Entrepreneurship Theory and Practice, 27(1), 47-63. https://doi.org/10.1111/1540-8520.271003

Navarrete, E., \& Sensores, E. (2011). Quintana Roo México micro, small and medium sized business failure: a multivariable analysis. Revista International Administración \& Finanzas, 4(3), 21-33. https://papers.ssrn.com/sol3/papers. cfm?abstract_id=1884519

Navarro, A., Rey, M., \& Barrera, R. (2017). Commitment, resources, export enterprise and business results. Revista de Administração de Empresas, 57(2), 135-147. https://doi.org/10.1590/s0034-759020170203

Navas, W. (2017). Investigación e innovación, factores de crecimiento en las PYMES. Revista Publicando, 12(2), 254-268. https://revistapublicando.org/revista/index.php/crv/article/ view/637

Nikolaeva, E., \& Pletnev, D. (2016). The role of the transaction costs in the business success of small and medium sized enterprises in Russia. Procedia - Social and Behavioral Sciences, 221(7), 176-184. https://doi.org/10.1016/j.sbspro.2016.05.104

Olejnik, E., \& Swoboda, B. (2012). SMEs' internationalisation patterns: descriptives, dynamics and determinants. International Marketing Review, 29(5), 466-495. https://doi.org/10.1108/02651331211260340

Ortiz, C., Jiménez, D., \& Cruz, G. (2019). The impact of infrastructure on economic growth in Colombia: A Smithian approach. Lecturas de Economía, (90), 97-126. https://doi.org/10.17533/udea.le.n90a04 
Oviatt, B., \& McDougall, P. (2005). The internationalization of entrepreneurship. Journal of International Business Studies, 36, 2-8. https://doi.org/10.1057/palgrave.jibs.8400119

Oviatt, B., \& McDougall, P. (2005). Defining international entrepreneurship and modelling the speed of internationalization. Entrepreneurship Theory and Practice, 29(5), 537-553. https://doi.org/10.1111/j.1540-6520.2005.00097.x

Paul, J., Parthasarathyc, S., \& Gupta, P. (2017). Exporting challenges of SMEs: A review and future research agenda. Journal of World Business, 52(3), 327-372. https://doi.org/10.1016/j.jwb.2017.01.003

Peter, Y., \& Burke, P. (2017). Company size. Technical Career Survival Handbook, 85-86. https://doi.org/10.1016/B978-0-12-809372-6.00033-5

Porter, M. (2009). Estrategia competitiva: técnicas para el análisis de la empresa y sus competidores. Piramide.

Ramos, R., Ramírez, V., López, M., \& Ramírez, A. (2010). Método de diseño para variedad de productos basado en el análisis de su modularidad. Ingeniería, Investigación y Tecnología, 11(1), 57-71. https://doi.org/10.22201/fi.25940732e.2010.11n1.006

Rivera, P., Sánchez, P., Romo, E., Jaramillo, A., \& Valencia, A. (2013). Perceptions of university students regarding learning through mobile devices. Journal of Education and Social Development, 7(2), 152-165.

Ruble, R., \& Versaevel, B. (2014). Market shares, R\&D agreements, and the EU block exemption. International Review of Law and Economics, 37, 15-25. https://doi.org/10.1016/j.irle.2013.04.008

Ruzzier, M., Hisrich, R., \& Antoncic, B. (2006). SME internationalization research: past, present and future. Journal of Small Business and Enterprise Development, 13(4), 476-497. https://doi.org/10.1108/14626000610705705

Saeed, A., \& Vincent, O. (2011). Financial obstacles to firm export: insight from a developing country. Journal of Transnational Management, 16(4), 204-220. https://doi.org/10.1080/15475778.2011.623964

Sánchez, I., Benítez, F., \& Arias, E. (2015). El precio en el marketing ( $7^{\mathrm{a}}$ ed.). UTMACH.

Sistema Integrado de Información de Comercio Exterior. (2019). Empresas exportadoras. Lima, de. http://www.siicex.gob.pe/siicex/portal5ES.asp?_page_=216.17100\#anclafecha
TradeMap. (2019). Lista de los mercados importadores para un producto exportado por Perú, de. https://www.trademap.org/ Country_SelProductCountry_TS.aspx?nvpm $=3 \% 7 \mathrm{c} 604 \% 7 \mathrm{c} \%$ 7c\%7c\%7c711311\%7c\%7c\%7c6\%7c1\%7c1\%7c2\%7c2\%7c1\%7 c2\% $7 \mathrm{c} 1 \% 7 \mathrm{c} 1 \% 7 \mathrm{c} 1$

Williamson, O. (1985). The economic institutions of capitalism. Free Press.

Wu, J. (2013). Marketing capabilities, institutional development, and the performance of emerging market firms: a multinational study. International Journal of Research in Marketing, 30(1), 36-45. https://doi.org/10.1016/j.ijresmar.2012.07.001

Xie, X., \& O'Neill, H. (2014). Learning and product entry: how diversification patterns differ over firm age and knowledge domains in U.S. generic drug industry. Strategic Management Journal, 35(3), 440-449. https://doi.org/10.1002/smj.2101

Xue, J., Yuan, H., \& Shi, B. (2016). Investigating partners' opportunistic behavior in joint ventures in China: The role of transaction costs and relational exchanges. Journal of Business Research, 69(12), 6067-6078. https://doi.org/10.1016/j.jbusres.2016.06.011

Yarba, I., \& Guner, N. (2020). Uncertainty, macroprudential policies and corporate leverage: Firm-level evidence. Central Bank Review, 20(2), 33-42. https://doi.org/10.1016/j.cbrev.2020.03.005

You, J., Chen, Y., Wang, W., \& Shi, C. (2018). Uncertainty, opportunistic behavior, and governance in construction projects: The efficacy of contracts. International Journal of Project Management, 36(5), 795-807. https://doi.org/10.1016/j.ijproman.2018.03.002

Zahra, S. (2005). A theory of international new ventures: A decade of research. Journal International Business Studies, 36(1), 20-28. https://doi.org/10.1057/palgrave.jibs.8400118

Zaizi. (2018). Over half of government departments are not futureproofing their digital transformation projects. Open Access Government.

Zhang, L., \& Qinzhen, Q. (2017). How mediated power affects opportunism in owner-contractor. International Journal of Project Management, 35, 516-529.

https://doi.org/10.1016/j.ijproman.2016.12.003 